\title{
In search of developing practical knowledge in pre-service EFL teachers: a proposed model
}

\author{
Sibel Ersel Kaymakamoğlu a* \\ ${ }^{a}$ European University of Lefke, Gemikonağı, Lefke/TRNC via PK 10 Mersin/Turkey
}

\begin{abstract}
APA Citation:
Kaymakamoğlu, S. E., (2019). In search of developing practical knowledge in pre-service EFL teachers: A proposed model. Journal of Language and Linguistic Studies, 15(3), 1000-1010.

Submission Date:24/06/2019

Acceptance Date:02/09/2019
\end{abstract}

\begin{abstract}
This study aimed to explore the ways of helping pre-service EFL (English as a Foreign Language) teachers gain and develop practical theories related to teaching EFL. For this purpose, the researcher devised a model primarily based on creating awareness on pre-service EFL teachers related to basic methodological knowledge of teaching besides their strengths and weaknesses related to their classroom practice in search of helping them to form practical knowledge needed for teaching. The model aimed to support the pre-service EFL teachers' practical knowledge construction by creating micro-teaching sessions in which they could put their theoretical knowledge into practice, feedback sessions in which they could receive teacher evaluation and peer evaluation, and engaging them into the process of self-reflection as well with the help of self-monitoring. The data were collected during 13 weeks in which every pre-service EFL teacher found 50- minute four micro-teaching session opportunities: two micro-teaching sessions for teaching reading and two micro-teaching sessions for teaching listening. 28 pre-service EFL teachers were the participants of the study. The data were collected from pre-service EFL teachers' selfevaluation reports, peer evaluation rubrics, lesson plans and teacher evaluation documents in each micro-teaching sessions in order to see the development if there was any during 13 weeks. At the end of the process, the student teachers were also asked to express their views about the process of learning and it was found that the proposed model created awareness in them about the difference between theoretical knowledge and practical knowledge. Besides, it helped their practical knowledge construction.
\end{abstract}

C 2019 JLLS and the Authors - Published by JLLS.

Keywords: Practical knowledge; pre-service EFL teachers; theoretical knowledge

\section{Introduction}

With the influence of postmethod paradigm, constructivist approach to teacher education which considers teachers as "active, thinking decision makers" (Borg, 2011, p. 218) has taken the place of traditional and transmission oriented view of teacher education. This paradigm puts emphasis on empowering the teachers to "theorize from their practice and practice what they theorize" (Kumaravadivelu, 2006, p. 173) stressing the overarching nature of reflective practice. Teachers' engagement in reflective practice can be seen in various approaches such as journal writing, classroom

\footnotetext{
* Corresponding author. Tel.: +90-392-660-2654

E-mail address: skaymakamoglu@eul.edu.tr
} 
observation, action research, classroom video analysis, examination of lesson plans, critical friendship and discussion groups (Farrell 2008). Some of these approaches are exercised individually while others require collaborative engagement.

Whatever approaches are adopted, understanding the process of learning is of paramount importance for pre-service teachers in order to teach effectively. According to Dinkelman (2003) "learning to teach means more than learning a set of tasks and procedures. Learning to teach means learning to inquire" (p.12).

However, conceptualizing the process of learning and teaching is a complex issue since it involves many dynamics that pre-service teachers need to be well aware of. This process can be regarded as a collaborative process as well as individual. In this process learning can be facilitated when the teacher trainer can create the learning environment in which learners are willing to learn, ready to go for challenges, can take risks, use effective strategies to make decisions and solve the problems at hand. It takes place in a social context where learners try to construct their own knowledge and influence the other pre-service teachers' knowledge construction. It should also be born in mind that the social context of learning is largely shaped by what learners and teachers bring with them into it such as learning experiences, beliefs, values, attitudes, assumptions, personal theories, knowledge, expectations, needs, strategies of learning, etc...Therefore, context of learning and teaching cannot be underestimated.

In this respect, the role of the teacher trainer cannot be disregarded since it is one of the responsibilities of him/her to create learning environments in which the pre-service EFL teachers can cognitively, affectively and intellectually grow. To obtain this, there is a need to support the pre-service EFL teachers experience learning and teaching in order to gain practical knowledge besides theoretical knowledge. With the help of this experience, learners can start to construct new understandings and meanings which can result in some sort of modification in their existing knowledge, or alteration or construction of new understandings that have never existed.

Keeping in mind what learners and teacher trainers bring with them into the learning context and the curriculum that needs to be followed, teacher trainers need to set up the learning environment for the pre-service EFL teachers well to be able to help them construct their own practical knowledge. They can construct their meanings and understandings with the help of the tasks and activities that they engage into. Yet, creating opportunities to help them construct practical knowledge is a challenge since such knowledge can only be gained with experience.

Therefore, there is a need for pre-service EFL teachers to teach, get into the process of reflection, get feedback as much as possible and thus become well-aware of their own strengths and weaknesses while getting experienced in teaching. However, challenging beginning teachers in order to understand and claim their agency as reflective teachers is taxing and complex work (Dinkelman, 2003). Therefore, there is a need for pre-service EFL teachers to understand that they can learn when they engage into reflective practice and when they are eager to learn through continuous experiential learning process. All in all, experience is needed for reflective practice yet it should be kept in mind that "experience teaches nothing to the non-reflective practitioner" Dinkelman, 2003, p. 9). In this respect, it is important to understand Kolb's Experiential Learning Theory (1984) and Shön's 'reflection-in-action' and 'reflection-on-action' (1983) to realize the essentials of learning for teaching better.

\subsection{Experience and Reflective Practice}

Experience is indispensible part of learning for teaching and developing practical knowledge for preservice EFL teachers. In the cycle of learning, not only experience but also observation and reflection are important. In this respect, Kolb's Experiential Learning Theory (1984) considers the process of learning as an amalgam of 'experience, perception, cognition and behavior' (p.21). This theory 
highlights the dialectical and cyclical nature of learning and regards learning consisting of four stages: experience, observation and reflection, abstract reconceptualization, and experimentation. In Kolb's Experiential cycle, experience is regarded as the source of learning and without reflection it cannot be achieved. Therefore, experience for reflection is seen as a must for learning. Similarly, Shön (1983) puts reflective practice in the center of learning and introduces two concepts for learning from teaching: 'reflection-in-action' and reflection-on-action'. According to Schön, in order for teachers to learn they need to go through both processes. 'Reflection-in-action' is the process of reflection while teaching which happens spontaneously and helps teachers evaluate and have a critical look at their teaching to make quick decisions when needed. Whereas the latter one, 'reflection-on-action', is the process of reflective practice that the teachers get into after teaching to evaluate their practice and decisions. Both processes are believed to help teachers gain new understandings and perspectives for teaching and learning, and thus facilitate their learning by engaging them into critical evaluation of their practice and decisions.

In my view, in teacher education programs the learners are mostly equipped with theoretical knowledge about learning and teaching yet there has always been a gap that the theoretical knowledge cannot be easily turned into practical knowledge. There can be several reasons of this such as the contextual realities and the nature of the curriculum. It should be admitted that turning theoretical knowledge into practical knowledge in teaching is challenging due to the dynamics of teaching context. To address this gap, in this study, the researcher (who was also an EFL teacher trainer and the lecturer of the class) devised a model that can help the pre-service EFL teachers' practical knowledge construction as well as bridging theoretical knowledge and practical knowledge. The model aimed to support the student teachers' practical knowledge construction by creating micro-teaching sessions in which they could put their theoretical knowledge into practice, by organizing feedback sessions in which they could receive teacher evaluation and peer evaluation and by engaging them into the process of selfreflection as well with the help of self-monitoring.

Therefore, in this study the researcher aimed to create the needed learning conditions and the activities that can help pre-service EFL teachers go into the process of reflective practice based on experience to help them develop practical knowledge besides theoretical knowledge. Micro-teaching sessions were organized to bridge the theoretical knowledge and practical knowledge for teaching since micro-teaching is seen as a valuable instructional tool that mediates between theory and practice (Benton-Kupper, 2001; Wahba, 1999) and beneficial for peers to provide constructive tips and suggestions, gain new ideas and strategies and be able to discern strengths and weaknesses in teaching (Benton- Kupper, 2001).

Peer-observations were organized because peer observation is one of the most common forms of collaborative professional development, and it could be a source of reflective analysis for teachers (Todd, 2017). In a similar vein, peer observation is seen as a useful tool that allows teachers to talk about and reflect on their own and each other's teaching, which leads to broadening their perspectives (Donnelly, 2017) and it is regarded as useful for teachers' personal growth, self-reflection as well as enhancing collegiality and collaboration among them (Hirsh, 2011). Creating opportunities for preservice EFL teachers also contributes to social interaction between and among the pre-service EFL teachers by providing a collaborative learning environment. Vygotsky's (1978) developmental theory claims that social interaction is a must for individual learning because learning is socially and culturally constructed (Morris \& Stew, 2007). Karagiorgi (2011) stated that "reflective dialogue and social interaction with peers are significant" (p.80). In a similar vein, Eun (2010) emphasized that "Collaboration among teachers allows for various types of expertise to be shared and internalized" since "each participating teacher in the collaboration process is an expert in some aspects and a novice in others" (p. 325). 
Self-monitoring was also conducted because

“...self-monitoring can help teachers better understand their own instructional practices and make decisions about practices they are not aware of and might wish to change. It can help teachers develop a more reflective view of teaching, that is, to move from a level where they are guided largely by impulse, intuition, or routine to a level where actions are guided by reflection and self-awareness" (Richards \& Farrell, 2005, p.37).

Due to the value of individual and collaborative reflection that contributes to teachers' learning, both forms were employed since both are considered to be complementary. Moradkhani (2019) asserted that "In order to maximize their effectiveness, teacher educators are recommended to use a mixture of both" (p.61).

\subsection{Research questions}

This study specifically aimed to answer the following research question:

- What are the views of the pre-service EFL teachers about the model which involved the teacher learning approaches to enhance the construction and development of their practical knowledge of teaching?

\section{Method}

\subsection{Participants}

The participants of this study were twenty-eight (28) second year pre-service EFL teachers who were enrolled into 'Methodology I' course which is a course offered to the pre-service EFL teachers in the Spring term of the second year in the English Language Teaching Department curriculum. The participants were 7 male and 21 female pre-service EFL teachers whose age ranged between 19 and 30 . Two of the participants were Turkish Cypriot, one participant was from England and the rest of them were from different parts of Turkey. Three participants were studying ELT as their second major. The course comprised of four sessions each week with primary focus on giving practical tips, suggestions and guidance based on theoretical issues for teaching the receptive language skills followed by preservice EFL teachers' micro-teaching sessions. The participants were required to teach the receptive skills because Methodology I was a course offered to them in the Spring term which will be followed by Methodology II in the fall term and the teacher trainer divided the teaching of the language skills in two terms as: the receptive skills in Spring and the productive skills in Fall term.

\subsection{Instrument( $s)$}

\subsubsection{Self-evaluation Reports}

Every pre-service EFL teacher was asked to have his/her micro-teaching session video-recorded. Then, they were required to write a self-evaluation report based on their video-recording.The report consisted of two sections: 'Description of the Lesson', 'Evaluation of the Lesson'. In the 'Description of the Lesson' part the pre-service EFL teachers were required to describe the lesson step by step. In the 'Evaluation of the Lesson' part they were asked to write the strenghts and weaknesses of their own teaching.

\subsubsection{Micro-teaching Sessions}

Every individual pre-service EFL taecher taught 50-minute two reading lessons and two listening lessons. Every lesson consisted of three stages: pre-, while- and post-.The pre-service EFL teachers were 
required to design communicative tasks appropriate for pre-intermediate level young adults. They were required to teach adopting learner-centered principles of learning and teaching.

As mentioned earlier, every individual pre-service EFL teacher taught every skill two times because the researcher wanted to see to what extent the feedback received by each pre-service EFL teacher for the first micro-teaching would reflect into and better the second microteaching. There were minimum three weeks between the first and second microteaching in order to give some time to each pre-service EFL teacher who taught to understand, digest and reflect and at the same time learn from other preservice EFL teachers that they observed and evaluated to shape their own thinking and learning. At the end of the process (13 weeks), the pre-service EFL teachers were asked to express their views written about the process of learning. For the anaysis of the collected data, content anaysis was carried out to find the recurring themes.

\subsubsection{Interview}

At the end of 13 weeks, the researcher scheduled a meeting with the participant pre-service EFL teachers to give them a pencil-interview. The interview questions were open-ended besides yes/no questions. There were eight questions designed to collect data about the participant pre-service EFL teachers' views about micro-teaching sessions, peer observations and evaluations, self-monitoring and evaluation and the model designed as the combination of all. The participant pre-service EFL teachers were given as much time as they wished to answer the questions in a comfortable environment because the researcher wanted to reach at the partcipant pre-service EFL teachers' opinions. The interview questions were as follows:

Have you benefitted from the micro-teaching ssessions? If yes, how? If no, why?

Have you experienced any difficulties during the micro-teaching sessions? Explain.

What do you think about teaching every skill two times?

Have you benefitted from peer observation and evaluation process? If yes, how? If no, why?

Have you experienced any difficulties during the peer observation and evaluation process? Explain.

Have you benefitted from the self-monitoring and evaluation process? If yes, how? If no, why?

Have you experienced any difficulties during the self-monitoring and evaluation process? Explain.

What are your views about the whole process of learning and teaching you have experienced in this process during 13 weeks?

\subsection{Data collection procedures}

The data were collected during 13 weeks in which every pre-service EFL teacher found 50- minute four micro-teaching session opportunities to teach receptive skills interactively: two micro-teaching sessions for teaching reading and two micro-teaching sessions for teaching listening.

The data were collected from pre-service EFL teachers' self-evaluation reports, peer evaluation rubrics, lesson plans and teacher evaluation documents in each micro-teaching sessions in order to see the development if there was any during 13 weeks.

\subsection{Data analysis}

The collected data was analyzed qualitatively. The researcher read the responses of the participant pre-service EFL teachers to the interview questions to carry out content analysis. As a result of this process, the researcher tried to group the responses by using color coding. Then, the researcher asked a 
colleague to carry out content analysis to compare her and the colleagues'. Then, the two was compared and reached on a consensus for the inter-rater reliability of the findings. The analysis of the findings revealed that all the participants found the microteaching sessions, peer observation and evaluation, selfmonitoring and self-evaluation and the model devised beneficial. However, six participant pre-service EFL teachers articulated the nervousness the microteaching process created on them. Besides, twentyfive participant pre-service EFL teachers indicated that engaging learners in learning tasks was a problem while teaching during the micro-teaching sessions. Considering the peer observation and evaluation process, twelve participant pre-service EFL teachers emphasized that the rubric was tiring to complete while observing. Regarding the self- monitoring and self-evaluation process, six participant pre-service EFL teachers expressed the technical problems they encountered during the video-recording of their own teaching.

\section{Results}

The views of the pre-service EFL teachers about the model which involved the teacher learning approaches to enhance the construction and development of their practical knowledge of teaching:

The analysis of the findings related to the views of the participant pre-service EFL teachers about the teacher learning approaches revealed different views about peer observation and evaluation, selfmonitoring and reflection and microteaching. In general, although all the participant pre-service EFL teachers articulated the benefits they gained from the reflection procedures they went through, they also expressed the problems they experienced during these processes.

\section{Microteaching}

With reference to microteaching sessions, all the participant pre-service EFL teachers found them very useful and necessary for learning how to teach. For instance, T3 (teacher 3) stated that

Microteaching sessions are needed before going to practicum. We have been doing presentations in many lessons but microteaching is very different and gave us chances of teaching our peers to learn about teaching.

Six pre-service EFL teachers expressed the negative influence of their nervousness on their teaching performance. For example T7 stated that

I felt so nervous that I could not talk fluently. This influenced my self-confidence. The less confident I felt the more mistakes I made while teaching. I had problems in remembering the right words and I could not even listen to the responses of the students.

Yet, all the participant pre-service EFL teachers also admitted the value of engaging in more than one microteaching experiences as helping them better their teaching.

I realized that my second microteaching was much better than the first one. The feedback I received from my peers, my teacher and the self-observing my own teaching from the videorecording enabled me to see my mistakes obviously. So in the second microteaching I tried not to make the mistakes that I made in the first. (T2)

However, 25 pre-service EFL teachers expressed their worries about not being able to engage learners in the tasks they gave most of the time.

The students did not help me in doing the tasks. I put them into groups for discussion but they did not talk and did not do the tasks that I gave them. It demotivated me because I expected my friends to contribute my lesson by responding and doing the tasks I gave them. (T3)

\section{Peer observation and evaluation}


With reference to the peer observation and evaluation process, the participant pre-service EFL teachers expressed the value of learning from their peers and the value of awareness created in them regarding their teaching. Besides, they articulated the benefit they received while evaluating their peers since the observation and evaluation procedures also helped their own learning for teaching.

All the participant pre-service EFL teachers expressed the benefit of using the peer observation rubric while twelve of them expressed the problems they experienced when using the rubric for peer evaluation.

I found the rubric very useful because it helped me focus on the points I needed to observe. So it narrowed down my focus of attention and observed the teacher to fill in those parts. (T1)

I found completing the rubric tiring because there were so many things to focus on while observing. (T27)

All the participant pre-service EFL teachers found the peer observation process useful for their own learning.

I realized that while I was observing my peers for evaluation I also questioned my own teaching which helped me learn to teach better. Trying to evaluate my friends enabled me to develop a critical look into my own learning for teaching. (T18)

\section{Self-monitoring and self-evaluation}

All of the participant pre-service EFL teachers found self-monitoring the most effective way of learning because they stated that the process helped them become aware of their own strengths and weaknesses in teaching.

Watching my own video-recording helped me realize how I teach. When somebody tells you about your strengths and weaknesses, you do not find it as effective as when you see them yourself. Until you see you do not really understand. Sometimes when you see you realize that you are not really aware of it. (T4)

Twenty participant pre-service EFL teachers articulated that self-observation and evaluation of their own teaching helped them question their thinking, their decisions and behaviors about teaching. They believed that this questioning process contributed their learning positively.

It was the first time that I video-recorded my own teaching. When I watched it for my selfevaluation later, I got surprised by the certain teaching behaviors I adopted. It gave me a chance to question my own thinking, decisions and behaviors about teaching and learning. (T19)

Six participant pre-service EFL teachers experienced technical difficulties in recording themselves.

I was not aware that the memory capacity of my phone was not enough to record my teaching.

In general, although the participant pre-service EFL teachers articulated the benefits and the drawbacks of the process of learning for teaching, they all expressed that the model proposed helped them learn and created awareness in them regarding their strengths and weaknesses. It seems that having three different supportive processes for reflection and practicing enabled them to experience teaching practically and putting the theoretical knowledge gained into practice. Therefore, it is likely that the process contributed to their practical knowledge construction. It seems that the pre-service EFL teachers found the model effective and beneficial. All of them stated that they found opportunities to get information from different sources which created awareness in them about their strengths and weaknesses in teaching.

First of all micro-teaching enabled me to experience teaching before going into real classroom. My friends' evaluations made me aware of the points that I should pay attention to while 
teaching. Later, watching my own video-recording helped me compare it with my friends' evaluations. (T19)

The process helped me understand that practice is very different than theory and the more you teach the better you get because you start to understand what you should do better next time and you try for the better next time. (T6)

\section{Discussion}

The findings of the study revealed that the participant pre-service EFL teachers found the model effective and useful. They also expressed the benefits and drawbacks of the teacher learning approaches yet in general, they articulated the support that the approaches provided them to better their teaching. They pointed out the necessity of having micro-teaching sessions before practicum. Ghanaguru et. al.'s (2013) study also supported the significance of practical knowledge through the use of microteaching for beginner teachers. The main benefit that they highlighted was that teaching every receptive skill two times helped them make the needed changes and teach for the better in their second teaching. Besides, they emphasized the benefits they gained with the help of peer evaluation process in which they engaged into reflective practice for each other and thus learned for themselves as well while providing feedback for their peers. Bell \& Cooper (2013) also found that peer evaluation helped improve teachers' teaching skills. With reference to self-monitoring and self-evaluation, the participant pre-service EFL teachers indicated that it was the most influential teacher learning approach compared to the others since it enabled them to watch their own teaching video-recorded by adopting a critical lens for it. Similarly, Eröz-Tuğa (2013) found that the participant pre-service EFL teachers indicated that the video-recording raised their awareness about classroom teaching. The findings revealed that this process created some sort of awareness in the pre-service EFL teachers about learning and teaching process and engaged them into critical and reflective thinking for learning and teaching. It seems that the process of reflection seems to help the participant pre-service EFL teachers' practical knowledge construction since it enabled them to reflect in and on action for their experiences in classroom teaching.

\section{Conclusions}

To sum up, although this study is limited to the specific context it was carried out in, it has the potential of creating awareness in ELT teacher trainers about the process of enhancing practical knowledge in pre-service EFL teachers. Keeping in mind the saying "practice makes perfect", there is a need for the pre-service teachers to benefit from created practical learning opportunities as much as possible to increase their practical knowledge repertoire relevant to learning and teaching process before going into real classrooms in practicum. Teacher trainers should not only provide them with various learning and teaching opportunities but also help them engage into reflective practice in order to learn the craft of teaching from experience. Learning for teaching cannot be thought of without practical experience and inquiry that are supported by reflective practice approaches for teachers to learn.

\section{Implications}

This study bears significance for being the only one in the Cyprus Turkish higher education context where EFL teacher training is carried out. It is different from the existing studies since such a study 
which proposes a model for the development of practical knowledge in the pre-service EFL learners by supporting them with a combination of three tools (micro-teaching, peer-observation and evaluation, self- monitoring and self-evaluation) does not exist in the relevant literature neither. With reference to the findings of this study, it seems that there is an urgent need to reshape the framework of teacher training curricula to house more practice-based courses in which pre-service EFL teachers can find opportunities to construct their practical knowledge besides theoretical knowledge starting from their first year first term. There is also a need to assign duties to the learners to experience reflective practice and critical thinking which can feed their thinking to improve their teaching.

\section{Acknowledgements}

I would like to thank all my students (the pre-service EFL teachers) who contributed to learning and teaching during 13 weeks and provided me the valuable data of this study. Besides, I would like to thank my colleague who helped me analyze the data to obtain reliable findings.

\section{References}

Bell, M. \& Cooper, P. (2013). Peer observation of teaching in university departments: A framework for implementation. International Journal for Academic Development, 18(1), 60-73.

Benton-Kupper, J. (2001). The microteaching experience: Student perspectives. Education, 121 (4), 830-835.

Borg, S. (2011). Language Teacher Education in J. Simpson (ed.). The Routledge Handbook of Applied Linguistics. New York: Routledge.

Dinkelman, T. (2003). Self-study in teacher education: A means and ends tool for promoting reflective teaching, Journal of Teacher Education, 54 (1), 6-18.

Eröz-Tuğa, B. (2013). Reflective feedback sessions using video recordings. ELT Journal, 67(2), 175183.

Eun, B. (2010). A Vygotskian theory-based professional development: Implications for culturally diverse classrooms. Professional Development in Education, 37 (3), 319-333.

Farrell, T. (2008). Reflective Language Teaching: From Research to Practice. London: Continuum Press.

Ghanaguru, S., Nair, P. \& Yong, C. (2013). Teacher trainers' beliefs in microteaching and lesson planning in a teacher training institution. The English Teacher, XLII(2), 104-116.

Hirsch, L. (2011). Utilizing Peer Observation as a Professional Development Tool. Doctoral Dissertation submitted to Northeastern University, Education Doctoral Thesis. Available at http://hdl.handle.net/2047/d20002427.

Karagiorgi, Y. (2011). Development of Greek Cypriot teachers professional identities: Is there a sense of growth? Professional Development in Education, 38 (1), 73-93.

Kolb, D. A. (1984). Experiential Learning: Experience as the Source of Learning and Development (Vol. 1), Englewood Cliffs, NJ: Prentice-Hall.

Kumaravadivelu, B. (2006). Understanding Language Teaching: From Method to Postmethod, New Jersey: Lawrence Erlbaum Associates. 
Moradkhani, S. (2019). EFL teachers' perceptions of two reflection approaches, ELT Journal, 73 (1), 61-71.

Morris, J. \& Stew, G. (2007). Collaborative reflection: How far do 2:1 models of learning in the practice setting promote peer reflection? Reflective Practice,8 (3), 419-432.

Richards, J. C. \& Farrell, T. S. C. (2005). Professional Development for Language Teachers, New York, Cambridge University Press.

Shön, D. A. (1983). The Reflective Practitioner: How Professionals Think in Action, San Francisco, Jossey Bass.

Todd, M. A. (2017). Peer observation as a tool for professional development. Culminating Projects in English. 84. Available online at http://repository.stcloudstate.edu/engl_etds/84.

Vygotsky, L. S. (1978). Mind in Society: The Development of Higher Psychological Process. Cambridge, MA: Harvard University Press.

Wahba, E. H. (1999). Microteaching. English Teaching Form Online, 37 (4).

\section{İngilizce öğretmenliği öğretmen adaylarının sınıf içi uygulama bilgisinin geliştirilmesine yönelik bir çalışma: Önerilen model}

\section{$\ddot{O} \mathbf{z}$}

Bu çalışma İngilizce'yi yabancı bir dil olarak öğretecek öğretmen adaylarına sınıfiçi uygulamalar için gerekli olan teorilerini kazanmaları ve geliştirmelerine yardım edecek yolları araştırmayı hedeflemiştir. Bu amaçla araştırmacı, İngilizce Öğretmenliği öğretmen adaylarının öğretme ile ilgili yöntembilimsel bilgileri ve sınıfiçi uygulamalarına yönelik güçlü ve zayıf yönleri hakkında farkındalık yaratarak öğretme için gerekli olan sınıfiçi uygulama bilgilerini oluşturmalarına yardım etmek amacı ile bir model geliştirmiştir. Bu model, öğretmen adaylarını sınıfiçi uygulama bilgilerini oluşturmalarında teorik bilgilerini sınıfiçi uygulama bilgilerine dönüştürebilecekleri küçük ölçekli öğretim imkanları sunarak, öğretmen ve akran değerlendirmeleri yoluyla geribildirim alacakları imkanlar sunarak ve öz-izleme yöntemi neticesinde gerçekleştirecekleri öz-değerlendirme imkanları sunarak desteklemeyi hedeflemiştir. Araştırmanın verileri 13 hafta boyunca her öğretmen adayının gerekleştirdiği 50şer dakikalık 4 küçük ölçekli öğretim (2 okuma, 2 dinleme) imkanı neticesinde toplanmıştır. Bu çalışma İngilizce Öğretmenliği Bölümü'nde okuyan 28 öğretmen adayı ile gerçekleştirilmiştir. 13 hafta süresince öğretmen adaylarının herhangi bir gelişme gösterip göstermediğini görmek amacıyla çalışmanın verileri her küçük ölçekli öğretimle ilgili öğretmen adaylarının öz-değerlendirme raporları, akran değerlendirme raporları, ders planları ve öğretmen değerlendirme dökümanları vasıtasıyle toplanmıştır. 13 hafta sonunda, öğretmen adaylarına öğrenme süreci ile alakalı düşünceleri sorulmuş ve önerilen modelin öğretmen adaylarında teorik bilgi ile sınıfiçi uygulama bilgisinin farklılığı konusunda farkındalık oluşturduğu saptanmıştır. Aynı zamanda, sürecin sınıfiçi uygulama bilgisi oluşumuna yardımcı olduğu bulunmuştur.

Anahtar sözcükler: sınıfiçi uygulama bilgisi; İngilizce Öğretmenliği öğretmen adayları; teorik bilgi

\section{AUTHOR BIODATA}

Assist. Prof. Dr. Sibel Ersel Kaymakamoğlu received her BA, MA on TEFL and EdD on TESOL. She has been a lecturer and teacher trainer of EFL at the Department of English Language Teaching, Dr. Fazıl Küçük Faculty of 
Education, European University of Lefke. She has carried out research studies on teacher beliefs, teacher cognition, teachers' practical knowledge, teachers' craft knowledge, teachers' professional development, learner-centered teaching, constructivist learning, learner beliefs and learner autonomy. 